\title{
СЕМАНТИЧНА РЕПРЕЗЕНТАЦІЯ ТА ФУНКЦІОНУВАННЯ КОНЦЕПТУ ПАМ'ЯТЬ
}

\section{Остапчук Я. В.}

\section{ВСТУП}

Властивий мові спосіб концептуалізації дійсності є універсальним, 3 іншого боку, - національно специфічним, таким чином, носії різних мов сприймають світ крізь призму своїх мов, що дає змогу стверджувати, що мовна картина світу втілює в собі зафіксований у мовних формах спосіб світосприйняття і світобачення певного народу. Одним зі шляхів реконструкції мовної картини світу є аналіз концептів як ментальних утворень, що водночас $\epsilon$ базовими одиницями мисленнєвого коду людини та являють собою результат пізнавальної діяльності суспільства, передають комплексну інформацію про позначуваний предмет чи явище й інтерпретацію суспільного відношення до цього явища чи предмета.

Концептуальний аналіз, що передбачає моделювання й опис концептів як ключових квантів структурованого знання, представлений насамперед у працях Ю. Апресяна, Н. Арутюнової, М. Джонсона, В. Кононенка, О. Кубрякової, Дж. Лакоффа, О. Селіванової, Б. Успенського. У сучасному мовознавстві використовують різноманітні методики опису й вивчення концептів: метод профілювання (Е. Бартмінський), теорію імен-гештальтів (Л. Чернейко), теорію вертикальних синтаксичних полів (С. Прохоров), теорію вертикального контексту (О. Ахманова та I. Гюббенет), метафоричний аналіз (Дж. Лакофф і М. Джонсон), метод фреймової семантики (Ч. Філмор), метод прототипових сценаріїв (Р. Шенк та Р. Абельсон), метод когнітивних прототипів (Е. Рош i Дж. Лакофф), фреймовий підхід (С. Жаботинська), польовий підхід (Й. Стернін), метод семантичних примітивів (А. Вежбицька), методику ключових слів (В. Маслова), методику вивчення культурних домінант (В. Карасик), концепцію метафоричної сполучуваності імені концепту (В. Телія, О. Кондратьєва) та ін.

До апробованих методів дослідження концепту, що передбачають встановлення мовних засобів його вираження, належать дефініційний аналіз, компонентний аналіз, етимологічний аналіз, вивчення концептів через лексико-граматичне поле лексеми, що його репрезентує, 
побудова синонімічного ряду, стилістична інтерпретація, методика фреймового моделювання, застосування інструментарію теорії когнітивної метафори, асоціативний експеримент, когнітивносемантичний, зіставний аналіз концептів у різних культурах, когнітивна інтерпретація результатів опису семантики мовних одиниць, верифікація отриманого когнітивного опису у носіїв мови тощо. Проте, зважаючи на складність явища, цілі та мету дослідників, неоднаковий підхід до розуміння концептів, є ще достатня кількість нерозв'язаних питань, пов'язаних із методологією вивчення концептів.

Вираження концепту - це сукупність мовних і немовних засобів, що прямо або опосередковано ілюструють, уточнюють і розвивають його зміст. Метою концептуального аналізу $\epsilon$ виявлення парадигми культурно значущих концептів й опис їх концептосфери ${ }^{1}$.

У мові концепти реалізуються одиницями різних мовних рівнів лексемами, фразеологізмами, приказками та прислів'ями, граматичними формами, синтаксичними структурами та текстами. Позначаючи той чи інший концепт, вони активізують відповідний когнітивний контекст, при цьому складним питанням залишається визначення кордонів мовного значення й загального енциклопедичного. Дискурс виявляється водночас й «середовищем перебування», i «засобом реалізації концептів», і тими позначеннями, що впливають на їх зміну й розвиток ${ }^{2}$.

Обов'язковою передумовою концептуального аналізу у цьому напрямі $\epsilon$ не лише семантичний аналіз його імені та інших номінативних одиниць, що його репрезентують (дефінітивний, етимологічний, частиномовний аналіз, встановлення синонімічного та антонімічного рядів), а й верифікація отриманих даних вивченням дискурсивних реалізацій засобів вербалізації концепту з опертям на методики дискурс-аналізу, що дає змогу встановити як його базові семантичні ознаки, так і асоціативно-образні, що відбивають усі стереотипізовані знання, уявлення, вірування, образи, оцінки, припущення, упередження, очікування тощо, асоційовані з феноменом, що репрезентує концепт.

\section{1. Вербалізація та семантичне наповнення концепту ПАМ'ЯТЬ}

Осмислення і пізнання світу є невід'ємною частиною мисленнєвої та мовної діяльності. Феномен пам'яті ізоморфний таким глобальним

${ }^{1}$ Карасик В.И. Языковая личность: аспекты лингвистики и лингводидактики. Волгоград : Перемена, 1999. С. 69.

2 Мартинюк А.П. Концепт у дискурсивній парадигмі. Вісник Харківського національного університету ім. В.Н. Каразіна. Харків : Константа, 2006. С. 11. 
категоріям, як знання, мислення, свідомість, усвідомлення, розуміння. Подібно до інших абстрактних концептів концепт Пам'ять має когнітивну природу, відображаючи зв'язки та закономірності, що існують у світі та свідомості індивіда. За його допомогою відбувається процес усвідомлення та категоризації знань та уявлень, узагальнення людського досвіду, організовуються пізнавальні властивості.

Пам'ять можна трактувати як форму існування і систематизації результатів пізнавальної діяльності людини; суб'єктивний образ об'єктивної реальності, тобто адекватне відображення зовнішнього і внутрішнього світу у свідомості людини в формі спогадів; у широкому смислі - це сукупність теоретичних надбудов, понять і уявлень, у вузькому - дані, інформація.

Як зазначає С. Рубінштейн, «без пам'яті ми були б істотами миттєвості. Наше минуле було б мертвим для майбутнього. Теперішнє, в міру його протікання, безповоротно зникало б у минулому. Не було б ні заснованих на минулому знань, ні навичок. Не було б психічного життя, злитого в єдності особистої свідомості, і не можливий був би факт по суті безперервного навчання, який проходить через усе наше життя і робить нас тим, чим ми $є)^{3}$.

Пам'ять у теорії пізнання визначають як одну із пізнавальних здатностей, яка полягає у мимовільному закріпленні, збереженні i відтворенні у свідомості суб'єкта здобутих у процесі пізнавальної діяльності відомостей про суб'єктивний і об'єктивний світи, результати їх творчої переробки, умов і способів відображення. Завдяки пам'яті суб'єкт спроможний примножувати свій минулий досвід, нагромаджувати знання й оперувати в уяві та мисленні образами замінниками реальних об'єктів, поняттями та уявленнями ${ }^{4}$.

3 метою виявлення істотних ознак визначуваного поняття, предмета або явища дослідники доволі часто використовують метод аналізу словникових дефініцій лексем-вербалізаторів концепту, що дає змогу представити концепт у вигляді стислих логічних визначень. Так, дефініційний аналіз однойменної лексеми пам'ять, що є ключовою для концепту Пам'ять, виявив такі значення концепту:

1) здатність запам'ятовувати, зберігати і відтворювати в свідомості минулі враження; здатність особливо добре запам'ятовувати що-небудь або користуватися якимось органом чуттів;

2) запас вражень, що зберігаються в свідомості і можуть бути відтворені;

${ }^{3}$ Рубинштейн С.Л. Основы общей психологии. Санкт-Петербург : Издательство «Питер» 2002. С. 323.

4 Філософський енциклопедичний словник / За заг. ред. В.І. Шинкарука. Інститут філософії ім. Г.С. Сковороди НАН України, Київ : Абрис, 2002. С. 463. 
3) згадка про кого-, що-небудь; те, що нагадує про кого-, щонебудь; згадка про померлого 5 .

Дефініційний аналіз лексеми пам'ятати, що $\epsilon$ наступним за важливістю репрезентантом концепту Пам'ять, окрім уже зазначених, окреслив такі значення концепту:

«Зберігати в пам’яті, не забувати»: Один проживе життя тихо, спокійно, а помре, то ніхто й не помітить, щзо такий чоловік $і$ жив на світі. А другий такий після себе слід залишає, щзо ияілі покоління про нього пам'ятають (Г. Тютюнник);

«Усвідомлювати, розуміти»: Я й не пам'ятаю, як мати ввели мене в хату, як поблагословили! Подавали рушники (я винесла щуонайкращчий, вишиваний) та й заручили нас (Марко Вовчок);

«Мати на увазі, враховувати»: Пам'ятай, Гайдаю, той перестає бути більиовиком, хто починає боятися маси, хто не вірить ї̈... (О. Корнійчук);

«Знати»: Хапко - бісик з освітою, зна, - кому яка одповідь годиться... Справний бісик любує садками,.. а своє діло добре пам'ятає (Марко Вовчок);

«Здатність розумно, тверезо мислити, міркувати; свідомість»: Пітьма заступила очі, пам'ять покинула мене... (І. Франко).

За семантичними маркерами ці лексеми можна об'єднати в декілька поняттєвих блоків:

пам'ять як когнітивна функція, що полягає у запам'ятовуванні, пам'ятанні чи забутті інформації, втрата пам'яті асоціюється із втратою цієї функції: Погано, правда, було з Костем Гнатовичем, він зовсім утратив пам'ять, майже нікого не впізнавав, тяжкі болі його мордували, і ніякої ради їм, ніякого ліку (В. Шкляр);

пам'ять як контейнер інформації, спогадів: У пам'яті я збережу навік $і$ вчительки уважність обережну, $i$ з другом батька бесіду бентежну (М. Бажан); Від рясного читання на селі він зберіг, щуоправда, в пам'яті силу імен, назв та змістів, але все цуе було подібне на занедбану бібліотеку, де книжки навіть на полиці не поставлено (В. Підмогильний); Він забув місие, де закопав рушниці й кулемет, $і$ изе було найтяжче забути та відсунути в такий далекий куток пам'яті, щзоб ніякий фізичний біль не долинув туди (Ю. Яновський); Мені стояло в пам'яті роками, як ми тоді не відали про те, чого старий тремтячими руками ловив секунди крильцее золоте (Л. Костенко);

пам'ять як спогад, де пам'ять асоціюється зі спогадом про якусь подію, ситуацію чи факт: Пам'ять про ияі звірства протриває сотні

${ }^{5}$ Словник української мови: в 11 т. / І.К. Білодід (голова) та ін. Київ : Наукова думка, 1970 1980. Т. 6, 1972. С. 39-40. 
років і чоловіком високої душі буде списана в книгу болю й скорботи, $i$ книга та навіки лишиться безіменною, бо хіба ж має ім'я пам'ять? (П. Загребельний); Гірка пам'ять війни, закодована в свідомості молодих матерів (П. Загребельний);

пам'ять як ознака свідомості: Якось на грані між пам'яттю й непритомністю до його обважнілого розуму почали добиратись розрізнені голоси (М. Стельмах).

Подальший аналіз відображень понять, закладених у концепті Пам'ять на мовному матеріалі, дає змогу виокремити такі значення концепту:

пам'ять як інструмент, який мовець задіює у разі пригадування: Геродот здивовано пружив пам'ять, бо не здогадувався, кому нахваляється його друг, а про нещасного метека Гіпербола йому й на думку не спадало (І. Білик); Вона напружує пам'ять, пригадує знаки азбуки Морзе (М. Трублаїні);

пам'ять як метафорична сутність, що спонукає людину до спогадів: Але пам'ять малювала в уяві лише сиву постать у кутку й нічого більще (М. Трублаїні); Пам'ять прискіпливо вибирала 3 минулого те, що розвіювало його останні сумніви: постійні якісь телефонні дзвінки, мовчання у трубку, Софіӥні походеньки до подружок, кравчинь, вічні ї̈ затримання на роботі, зрештою подружнє розхолодження й апатія до того, щуо колись так хвилювало $i$ збурювало кров (В. Шкляр).

Принциповим моментом вербалізації концепту Пам'ять $є$ спосіб його предикативного супроводу, а саме занурення слова в контекст дії i виявлення усього кола операцій, які можливі в полі запам'ятовування/пам'ятання/пригадування/забування. Аналіз мовного матеріалу засвідчує такі регулярні предикації концепту:

запам'ятовування інформації, внесення інформації в пам'ять: занести, внести, зафіксувати, закарбувати в пам'ять: Східиів не бачив, ступав навпомацки, та, виявляється, пам'ять закарбувала тут кожну сходинку, $i$ він ішов рівно, не спотикаючись (В. Шкляр); Меркурій Юхримович кивнув головою, але не пробачив, а вписав у пам'ять слова директора, щчо в иьому рочі більше підозри, ніж треба (П. Загребельний); Якби Теобальд носив зачіску із гривкою, иього могло б бути не видно, але чоло його відкрите, і така незвична риса обличчя відразу ж впадає в очі $і$ врізається в пам'ять (В. Шкляр); Легка моя пам'ять вбирала в себе одразу все, що їи подобалося (П. Загребельний);

володіння інформацією: мати в пам'яті, тримати в пам'яті: Ще засіло в пам'ять, як Полушка (він стояв у гурті лісорубів, зотлілий пеньок під шапкою-моховичкою) скрушно позіхнув, ніби тим 
підтвердив: така, брат, доля, нічого не вдієш, - $i$ дня не стало (В. Близнець); I нащадки зазвичай добре зберігають пам'ять (Брати Капранови); Їй почало здаватися, що пам'ять уже ввібрала у себе максимально можливу кількість інформації $і$ просто не здатна засвоїти більше, тому тепер їй достатньо просто пригадувати і поновому очінювати пережите (В. Шкляр);

користування пам'яттю як інструментом для відтворення спогадів: напружувати пам'ять: Як не напружував пам'ять Сашко, пробігаючи думкою по всіх дворах, але не міг уявити, у кого аж дотепер збереглося порося (В. Близнець); Марта напружила пам'ять, аби в точності відтворити той погляд, $і$ знову ледь не підскочила на місиі: так, так, в очах був переляк (І. Роздобудько); - Я тобі нагадаю, я тобі просвіжу пам'ять . Край дороги - пригадуєи? (Н. Бічуя);

відтворення інформацї̈: виринати, вставати, спливати, майнути, промайнути в пам'яті: Щось далеке й забуте, ніби аж з того світу, спливло ӥй на пам'ять: ніч, двоє в степу; Санько і вона, втікачка; над ними зорі південного степу, і він казав щчось хмільне... (В. Близнець); I хоч тепер мені важко сказати, де в цій історії початок, а де кінець, пам'ять насамперед вертає до того зимового дня, коли я знов опинився без даху над головою (В. Шкляр); I весь минулий вечір, розмова з Галею, з Фомушкою стали якимись иматками, в якімось дикім неладі приходити йому на пам'ять (В. Винниченко);

забування інформації: втрачати пам'ять: Пам'ять йому як одбило, в гарячиі й не помітив, куди подівся Гарба, чи є хто живий (В. Близнець); А потім все стихло, і пам'ять отерпла, $i$ він, мабуть, спав (В. Близнець); ... бо все одно не народиться дитина, яка може виявитися нешлюбною донькою мільйонера, що втратив пам'ять $i$ опритомнів тільки після того, як уперше побачив свою крихітку, на той час уже вісімнадиятирічну $i$ з апетитним бюстом (Н. Сняданко).

Аналіз синонімічного ряду лексеми пам'ятати та іiі антоніму лексеми забувати дає змогу виокремити такі семантичні маркери:

відтворення інформації, пошук інформації: згадати, згадувати, пригадувати, нагадати, нагадувати, здумати, здумувати, надумати, попам'ятати, спогадати: Згадала, як ми разом жили, як я тебе доглядала; Та згадала, як ото колись він усе викликав мене нашими ворітьли (М. Стельмах); Напружуючи пам'ять, пригадала, що на иььму годиннику ииферблат розбито не на дванадиять, а на двадиять чотири частини (М. Трублаїні);

володіння інформацією: пам'ятати, пам'ятувати: Я пам'ятаю вчительку мою, просту і скромну і завжди спокійну (В. Сосюра); Але й досі пам'ятую Ранок теплої весни (Я. Щоголів); 
втрата інформації: забути, забувати, забуватися, позабути, призабути, призабутися, призабуватися: Батько його помер скоро по війні, мати теж не зажилася на світі, рідню Андрій поступово забув, рідня забула його, $і$ вже ось добрих двадиять літ Приймак не навідувався до свого села - ніби одрізав, ніби й не існувало його ніколи на світі, того села (В. Дрозд); А щзо потрібувала поживи для розбудженого раз материнського чуття, тож стала чи не другою матір'ю для малої Тетянки, бо з часом стала Тетянка ніби ї̈ власною дитиною, $i$ вона заспокоїлася, призабула власну свою дитину (О. Кобилянська);

фіксація інформації: запам'ятати, запам'ятовувати, зафіксувати, зафіксовувати, фіксувати, затямити, затямлювати: - Ось вам, подав Кирило Васильович Тамарі якусь книжку. - Читайте, побільше запам'ятовуйте німецьких слів. Поки що це ваше бойове завдання (А. Хижняк).

Пам'ять може мати специфічний характер і стосуватись якогось 3 аспектів життя чи діяльності, як-от: ...бо моя зорова пам'ять на обличчя чомусь прачюе незалежно від моєї ж зорової пам'яті на прізвища, і тому я добре пам'ятаю і обличчя, і прізвища, тільки ніколи не впевнена, чиє обличчя відповідає чийому прізвищу, $i$ навпаки (Н. Сняданко); Соломія-Корнелія мала надзвичайно рідкісне колоратурне сопрано, абсолютний слух і унікальну музичну пам'ять (В. Близнець).

Подібно до інших когнітивних функцій пам'ять людини може бути розвинута різною мірою, що в мовному матеріалі знаходить відображення у формах словосполучень погана/чудова/блискуча/феноменальна пам'ять: Пам'ять у неї була чіпка, як глічинія (П. Загребельний); Я сподіваюся на вашу професійну пам'ять, вирішив полестити я, і не помилився (П. Загребельний); Він мав погану пам'ять на дати, $i$ Софія завжди нагадувала йому про дні народження та маленькі ювілеї їхнього родинного життя (В. Шкляр).

На позначення поганої пам'яті найчастіше використовуються словосполучення коротка пам'ять: Пам'ять коротка у ворогів, грають з вогнем... Та не вдається їм обдурити народ, погнати його на нову війну (І. Цюпа); - Вельми коротку пам'ять маєш, учителю, - лихо засміявся Савмак і притяг його за полу білого гіматія (І. Білик); куряча пам'ять: От уже куряча пам'ять - бачити людину і не згадати, де й коли... (Л. Смілянський); дірява пам'ять/голова: - Значить, у тебе дірява пам'ять (В. Мастерова); Чогось на старість у мене голова стала дірява (Ю. Мушкетик); стареча/ледача пам'ять: Гай-гай! стареча пам'ять! Виразно ж тут стоӥть, що жаден майстер на судьбищах не має промовляти (Леся Українка); В якійсь далекій 
стороні... В Німеччині... В Туреччині... Та ні! Таку ледачу пам'ять маю, Що й не згадаю (Л. Глібов).

Концепт Пам'ять має амбівалентну оцінку, що спричинена самою природою мнемічних процесів, які в різних життєвих ситуаціях можуть бути потрактовані по-різному. Процес забування може бути як негативним, так і позитивним, якщо йдеться про стирання в пам'яті непотрібної або неприємної інформації-спогадів: Раїса почувала себе добре, немов викинула з пам'яті все неприємне (М. Коцюбинський); Скочив [соловей] як попарений.. $i$ запищав не свойми голосами. Неначе хотів своїм лящанням викинути всім із пам'яті те, що зозуля вже обзивалася (Лесь Мартович). Пам'ять є невід'ємною частиною людського функціонування як живого організму: Нікуди не подінешся, не втечеш од своїх початків, від витоків, бо людина починається, як ріка, але від води різниться тим, що має пам'ять - ию найбільщу насолоду, але й найтяжчу муку водночас (П. Загребельний).

Пам'ять постає у мові як уявний пристрій чи орган, який активно функціонує, разом із тим як щось компактне, те, що має кордони, що частково відповідає психолінгвістичній інтерпретації пам'яті як набору активних процесів, а не статичної структури ${ }^{6}$. Як будь-який орган вона має локалізацію (в'їстися в мозок, в'їстися в печінки, тримати в голові, не спускати з думки, пронести в сериі), асоціюється з фізичними відчуттями (пам'ять болить, пече, тривожить; Пам'ять болить дужче за тіло (Н. Сняданко), може контролюватись зусиллями суб'єкта або функціонувати незалежно від його волі.

Фактичний матеріал показує, що згадування може поєднуватись 3 емоціями: $M и$ всі згадуємо ваш вчинок $з$ такою вдячністю (В. Козаченко); I він з огидою згадав, що забув рукавички в гостях; I Гудзик з досадою згадав, що він на сьогодні обіияв пану Яну послать до двору гарненьку дівчину від машини (В. Винниченко), тому пам'ять як уособлення спогадів людини може мати різноманітне емоційне забарвлення: Жорстока як пам'ять. Глибока як криниия (І. Роздобудько); Андрій зовсім не здивувався, щчо для нього та ніч теж стала особливою, а пориелянова берегиня, імені якої він так $і$ не спитав, надто відрізнялася від колишніх його жінок, - i пам'ять по собі залишила незвично тривку, болісну (В. Арєнєв).

У контексті української паремійної картини світу концепт Пам'ять тісно пов'язаний з добром і злом, що втілено в пареміях: Все добре пам'ятай, лихого уникай!; Добро пам'ятай, а зло забувай; Не поминай лихом, а добром, як хочеш, причому погана пам'ять триваліша за добру: Добре довго пам'ятається, а лихе ще довще; Хто в пір'я проростає,

${ }^{6}$ Залевская А.А. Введение в психолингвистику. Москва, 1999. С. 53. 
той за бідного не пам'ятає. Зневага до забудьків і роззяв зафіксована в пареміях: Забув, що й на боргу; Наӥвся забудьків (все забув); Ударив у губу та й забув рахубу; Памороки забив; Вийшли женці в поле жати та й забули серпи взяти.

Суб'єктом пам'яті може виступати як індивідуальний носій, так i суспільство, колектив. У такому разі вона асоціюється з вищими цінностями людства - добром, патріотизмом, честю. В основі індивідуальної пам'яті лежать механізми вищої нервової діяльності головного мозку, а колективна пам'ять виражається в проявах суспільно-історичного досвіду, суспільній свідомості: Бо вбити - не означає усунути з людської пам'яті. Пам'ять не належить ні королям, ні гетьманам, ні державі, ні иеркві - це єдине, чого не може відібрати в людей ніяка сила (П. Загребельний); До того ж ми давно вже почали формувати певну спільну пам'ять, пам'ять, що лежить поза межами досвіду окремого індивідуума (В. Арєнєв); Народ, лякаючись, що згине пам'ять його, мерщій виставляс наперед великого співия (П. Загребельний). Так, суспільна пам'ять відображає культурноісторичну своєрідність народу, виступає своєрідним місточком між минулим i сьогоденням, визначаючи орієнтири для сприяння соціальній і національній ідентифікації членів суспільства.

\section{2. Взаємодія концептів ЗНАННЯ і ПАМ'ЯТЬ}

Оскільки наслідком когнітивної діяльності є знання, воно тісно пов'язане $з$ пам'яттю, що є очевидним на вербальному рівні, коли пам'ять і знання семантично зближуються: Не мав куди йти [Сивоок], тож подався по низу вздовж уділля $i$ незабаром був уже коло Родимового обійстя, коло першого свого в житті дому, який знав $\boldsymbol{i}$ пам'ятав (П. Загребельний).

Дослідження концептів «знання» і «пам'ять» звичайно грунтуються на визнанні їхнього взаємозв'язку. Так, І. Фустер зазначає, що різниця між знанням і пам'яттю дуже незначна, оскільки знання - пам'ять про факти ${ }^{7}$; Р. Шанк і Р. Абелсон стверджують, що все людське знання грунтується на попередньому досвіді, причому новий досвід інтерпретується під призмою попереднього досвіду, а тому знання і пам'ять перебувають у тісній взаємодії. Приміром, у реченні Пригадались йому сумні розмови про панщину. Раніш иі розмови не дуже вражали хлопия - хотілось радощів, $і$ він одганявсь од них як од

${ }^{7}$ Fuster J.M. Cortex and Mind: Unifying Cognition. New York : Oxford University Press, 2005. P. 111-112.

${ }^{8}$ Schank R.C. Knowledge and Memory: The Real Story / ed. by R.S. Wyer. Hillsdale, NJ : Lawrence Erbaum Assosiates, 1995. P. 1-2. 
мух. Тепер лягли вони на нього всією страшною своєю вагою. Раб... невільник, довічний попихач. Не минеш того, не викрутишся (С. Васильченко) спогади, пам'ять про минулі події та явища зумовлюють усвідомлення власного становища.

Взаємозв'язком пам'яті і знання можна пояснити те, що у деяких контекстах знати=пам'ятати: Добре він знає, здавна знає ту степову корабельню (О. Гончар) - Добре він пам'ятас, здавна пам'ятає ту степову корабельню; Я знаю, що таке тил, коли ворог під стінами города (М. Хвильовий) - Я пам'ятаю, щуо таке тил, коли ворог під стінами города.

Якщо ідеться про інформаційну пам'ять, що включає знання (пам'ятати таблицю множення, рік взяття Бастилії чи масу Сонця), лексеми знати і пам'ятати є взаємозамінними: Сєня Кацман пам'ятав із иієї пісні лише перший рядок: «Ще не вмерла ...»-зате він знав, шьо ие страшенна крамола, яку треба випікати розпеченим залізом (М. Трублаїні) - знав=пам'ятав перший рядок пісні; однак якщо мовець пам'ятає якусь подію крізь призму свого враження від неї, заміна неможлива: Не бачив він радісних облич навколишніх, не пам'ятав нічого, окрім першого враження від зустрічі з коханою, чув лише оксамит ії голосу, відчував тепло коханого тіла $i$ гаряче дихання поряд (Ю.Сорока); Ніхто 3 людей бухти Ногая не пам'ятав такого шторму (М. Трублаїні).

Пам'ять, на відміну від знання, має ретроспективний характер, за висловленням М. Фортеск'ю, вона «звернена в минуле», тобто змістом пам'яті $\epsilon$ все те, що відбулось у минулому'. Щодо цього А. Айер висловлює припущення, що пам'ять може співвідноситись і 3 теперішнім, і з майбутнім. Учений наводить приклад: астроном може пам'ятати, що затемнення сонця відбудеться у майбутньому ${ }^{10}$. Однак, коментуючи цей приклад, варто зауважити, що інформація про затемнення була усвідомлена суб'єктом у минулому, а тому він згадує не саме затемнення, а відомості про нього. Так, у реченні Я пам'ятаю, що ми зустрінемось у наступний понеділок о четвертій, суб'єкт пам'ятає не зустріч, що відбудеться, а домовленість про цю зустріч, що мала місце в минулому.

Ретроспективним характером пам'яті можна пояснити неможливість функціонування виразів пам'ятати наперед, на відміну від знати наперед: Богдан знав наперед, хто то може бути (Н. Сняданко); Ти все знав наперед. (В. Шкляр).

\footnotetext{
${ }^{9}$ Fortescue M. Thoughts about thoughts. Cognitive Linguistics. 2001. Vol. 12, No. 1. P. 30-31.

${ }^{10}$ Ayer A.J. The problem of Knowledge. London : Macmillan and Co LTD; New York : St. Martin's Press, 1956. 258 p.
} 
М. Дмитровська вважає, що те, що міститься в пам'яті людини, становить фонд iі знань ${ }^{11}$. Л. Васильєв наголошує, що пам'ятати, згадати і забути можна тільки те, що збережено в свідомості як знання $^{12}$. Згадаймо український народний іронічний сталий вислів Не знав, не знав $i$ забув (Українські народні прислів'я та приказки), який демонструє, що неможливо забути те, чого не знаєш.

Однак варто зауважити, що зміст пам'яті не завжди є знанням, адже спогади можуть бути неточними або навіть неправдивими: Потім він, як крізь туман, пригадував собі ией крик (Ю. Андрухович); Вона здогадувалася, щзо бачила поганий сон, $i$ тепер з усіх сил напружувала пам'ять, щоб згадати його $i$ якось пояснити собi, розвіяти тривогу, але нічого не могла згадати, у голові шуміло, $і$ нішо там, у тій дурній голові, не трималося купи - ні думки, ні спогади (В. Шкляр).

А. Залізняк називає спогади «відбитками особистого досвіду» i наголошує, що факти, які ми пам'ятаємо чи забули, знаходяться в одному місці ${ }^{13}$. Наприклад, у реченні 3'ясовуєм подробииі, які чомусь досі не вивітрились з пам'яті, хоча, здавалось би навіщо, навіщо нам зараз серед иього шаленства хайвею уява виносить десь із глибини душі ту мовби раніш і забуту сагу дитячих літ (О. Гончар) пам'ять як сукупність спогадів людини знаходиться в глибині душі.

Досліджуючи механізми функціонування пам'яті i збереження інформації, психологи висловлюють різноманітні припущення, однак загальновизнаного характеру набула гіпотеза Дж. Андерсона i Г. Бауера, котрі зазначають, що «те, що носієм спогадів чи знань може бути дещо на зразок внутрішньої фотографії, кіно- чи відеострічки, яку ми можемо реактивувати чи відтворити, у разі нагадування образа не має наукової перспективи» ${ }^{14}$. Натомість, згідно із запропонованою концептуально-пропозитивною концепцією, пам'ять містить інтерпретацію подій у вигляді концептів, висловлювань, пропозицій.

Подібну думку поділяе і Е. Тульвінг. Аналізуючи довготривалу пам'ять, він виділяє два види знання: процедурне і пропозитивне ${ }^{15}$.

11 Дмитровская М.А. Глаголы знания и мнения : дис. ... канд. фил. наук : 10.02.01. Москва, 1985. С. 92.

12 Васильев Л.М. Семантика русского глагола. Москва : Высшая школа, 1981. C. 34 .

Зализняк А.А. Концептуализация забвения по данным русского языка. Когнитивное моделирование в лингвистике : материалы конференции. Москва : Инт языкознания РАН, 2004. С. 92-94.

${ }^{14}$ Anderson J.R., Bower G.H. Human associative memory. Washington DC : Winston and Sons, 1973. P. 453.

${ }_{15}$ Tulving E. Episodic and semantic memory. Organization of memory / ed. by E. Tulving, W. Donaldson. New York : Academic Press, 1972. P. 381-389. 
Процедурна пам'ять передбачає знання того, як здійснювати дії, що потребують певних навичок (пам'ятати, як їздти на велосипед $i$, користуватись Інтернетом тощо).

Пропозитивна пам'ять передбачає знання того, що відбулось i відповідає дійсності, це фактичне знання суб'єкта. Пропозитивне знання Е. Тульвінг ділить на епізодичне і семантичне. Епізодична пам'ять стосується особистих спогадів людини: Згадала вона все, що бачила в огні пожеж, тікаючи од німців через всю Вкрайну - попалену, розбиту, поруйновану (О. Довженко); Лукія пригадує, як в один із своїх приїздів капітан привіз Віталикові для забави мавпеня (О. Гончар); Нюся пригадувала, що за весь вечір дівчинка не промовила й слова, так $i$ заснула мовчки (В. Козаченко).

Семантична пам'ять передбачає запас знань, усвідомлених людиною незалежно від місця і часу: $Я$ знаю (пам'ятаю), що обманювати - погано. Це дає підставу припустити, що пропозитивна пам'ять стосується подій, явищ, ситуацій, сприйнятих і зафіксованих людською свідомістю у вигляді фактів.

Згідно з концепцією У. Чейфа, знання (інформація) знаходиться в активному чи неактивному стані, у різні періоди часу вона «включається» або не «включається» у потік свідомості людини, але як у першому, так і в другому випадку існує у свідомості людини ${ }^{16}$.

Отож, речення типу $X$ пам'ятає, що $Q=$ у певному часовому відрізку $X$ володіс знанням щодо факту $Q:$ Я пам'ятав, щчо в свойх барвистих розповідях про Одесу Береговенко ніколи не згадував про зв'язківияжінку (Ю. Збанацький). У цьому реченні пам'ятати=знати, володіти достовірною інформацією.

$X$ забув, що $Q=$ у певному часовому відрізку Х утратив знання щодо факту $Q$, що, однак, не впливає на реалізацію $Q:$ Магда враз забула, що посварилась з товаришками (Ю. Збанацький): Магда посварилась 3 товаришками - факт об’єктивної дійсності, що мав місце. Магда знала про ие. - Магда забула ичей факт.

$X$ згадав, що $Q=X$ у певному часовому відрізку $X$ відтворив знання щодо факту $Q:$ Я згадала, щчо сьогодні день відпочинку бібліотекарів (М. Хвильовий): суб'єкт володів знанням щодо факту сьогодні день відпочинку бібліотекарів і відтворив його; I тоді їй пригадалася призабута розповідь діда Корнія (М. Стельмах): суб'єкт знав зміст розповіді діда Корнія і відтворив цей факт.

На нашу думку, пропозитивна пам'ять - пам'ять суб'єкта про усвідомлені факти дійсності - пов'язана передусім 3 пропозитивним

16 Чейф У.Л. Память и вербализация пришлого опыта. Новое в зарубежной лингвистике. Москва : Радуга, 1983. Вып.12: Прикладная лингвистика. С. 37-38. 
знанням, що своєю чергою пояснює можливу взаємозаміну предикатів пам'ятати і знати: Домашні знали, щзо була вона мимовільним свідком (І. Вільде) - Домашні пам'ятали, щуо була вона мимовільним свідком ${ }^{17}$. Якщо ж знання стосується обізнаності у чомусь, розуміння принципів чи механізмів (знання-вміння), заміна знати на пам'ятати неможлива: знаю математику $\neq$ пам'ятаю математику, знаю, як працює метро $\neq$ пам'ятаю, як працююе метро.

Взаємозамінними є предикати знати і пам'ятати у заперечних контекстах: Не знаю, хто ти, де живеш (Л Костенко). - Не пам'ятаю, хто ти, де живеш. I перше і друге речення фіксують факт незнання суб'єкта.

Однак знання факту, що забувся, ще не гарантує його пригадування: Миготить щзось - от-от усе пригадаю... Проте ніяк не впіймається, тікає од мене, як пmax (С. Васильченко). Часом суб'єкт може відтворити у пам'яті тільки фрагмент цілісної картини. Таке епізодичне пригадування реалізується у конструкціях пригадую (згадую, пам'ятаю) тільки, щуо: Пам'ятала тільки, щуо звідкілясь їхала, поверталась до Києва $і$ чомусь опинилась у їхному майже дощенту випаленому в час Корсунь-Шевченківських боӥв містечку; Надійка пам'ятає тільки, щзо чекала на нього у скверику біля інституту $i$ хвилювалася (В. Козаченко).

Добре реконструйовані свідомістю факти представлені у конструкціях добре/чітко/ясно пам'ятала, щуо; добре/ясно/чітко згадала, щзо: Добре пригадували участь Богдана в повстанні Павлюка, коли він був військовим писарем (М. Грушевський); До дрібниць згадували вони свої щзоденні клопітні діла (Ю. Збанацький).

Фактичний матеріал засвідчує, що між фактом минулого і спогадом людини може пройти тривалий час: Згадав він про неї [крадіжку] через довгі роки (С. Васильченко); Федорові Несторовичу пригадалося, як у дитинстві ильопав босими ногами по розбитій чередою степовій дорозі, крута пилюга гарячими струмочками ціідлася крізь пальці, а вітерець виносив з-поміж кіп теплий дух спілого жита (Г. Тютюнник).

Поштовхом до згадування може бути якась теперішня подія, пов'язана 3 минулим: Дівчина торкнулась пальцями патрона $\boldsymbol{i}$ згадала, щзо так $i$ не показала їм знайденого листа таємничої незнайомки (В. Козаченко); Та на сходах зустрів «рябу людину з рябим голосом» $i$ враз пригадав усе (І. Білик), однак згадування може

17 Остапчук Я.В. Семантико-синтаксичні моделі речень 3 фактивними предикатами пам'яті. Наукові записки. Серія "Філологічна» : матеріали міжнар. наук.-практ. конф. Острог : Вид-во Національного університету «Острозька академія», 2010. Вип. 13. С. 499. 
відбуватись раптово: Раптом згадала, щзо забула зачинити двері, без видимих причин: I тут же згадав якусь сіру стенографістку, яка погоджувалась праџювати підряд сімдесят дві години (М. Хвильовий), навіть мимовільно, без потреби і бажання суб'єкта: Tym мимоволі згадується глибокодумна сентениія доктора Варфоломія Кнурия про сучасну прозу (П. Загребельний); Чомусь пам'ятаю, щзо річка звалась Леглич (Л. Костенко).

\section{ВИСНОВКИ}

Пам'ять належить до невід'ємних та найважливіших атрибутів людської свідомості, є одним з інструментів пізнання навколишнього світу і самопізнання, формування свідомості, уявлень про минуле та майбутнє, формою існування і систематизації результатів пізнавальної діяльності людини, суб'єктивним образом об'єктивної реальності

Дефініційний аналіз лексем пам'ять, пам'ятати, а також їх синонімів, звернення до мовного матеріалу дало змогу зафіксувати такі поняттєві блоки, що формують семантичне наповнення концепту: пам'ять як когнітивна функція; пам'ять як контейнер інформації, спогадів; пам'ять як спогад; пам'ять як ознака свідомості; пам'ять як інструмент, який мовець задіює під час пригадування; пам'ять як метафорична сутність, що спонукає людину до спогадів.

Принциповим моментом вербалізації концепту Пам'ять є спосіб його предикативного супроводу, а саме занурення слова в контекст дії i виявлення всього кола операцій, які можливі в полі запам'ятовування/пам'ятання/пригадування/забування. Аналіз мовного матеріалу засвідчує такі регулярні предикації концепту: запам'ятовування інформації; внесення інформації в пам'ять; володіння інформацією; відтворення інформації; втрата інформації.

В українській паремійній картині світу концепт Пам'ять тісно пов'язаний $з$ добром і злом, причому погана пам'ять триваліша за добру, зафіксована зневага до забудьків і роззяв.

Суб'єктом пам'яті може виступати як індивідуальний носій, так і суспільство, колектив. У такому разі вона асоціюється з вищими цінностями людства - добром, патріотизмом, честю. В основі індивідуальної пам'яті лежать механізми вищої нервової діяльності головного мозку, а колективна пам'ять виражається в проявах суспільно-історичного досвіду, суспільній свідомості.

Розглянуто основні аспекти взаємодії концептів Знання та Пам'ять, що разом з мисленням, мовою, сприйняттям становлять сутність буття людини. Окреслено контексти та умови, в котрих вони $\epsilon$ взаємозамінними. Так, лексема пам'ятати є еквівалентом знати, коли йдеться про інформаційну пам'ять. Іншим прикладом $\epsilon$ пропозитивна 
пам'ять - пам'ять суб'єкта про усвідомлені факти дійсності, що пов'язана з пропозитивним знанням.

Пам'ять, на відміну від знання, має ретроспективний характер, а основною характеристикою знання $\epsilon$ його істинність, тоді як зміст пам'яті може бути неточним, хибним або неправдивим.

\section{АНОТАЦІЯ}

На матеріалі українських лексикографічних джерел та фіксацій із текстів української літератури лексеми пам'ять, що є ключовою для концепту Пам'ять, а також лексеми пам'ятати виявлені його основні значення: когнітивна функція; контейнер інформації; спогад; ознака свідомості; інструмент, який мовець використовує під час пригадування; метафорична сутність, що спонукає людину до спогадів.

Розглянуто предикативний супровід концепту Пам'ять, а саме занурення слова в контекст дії і виявлення всього кола операцій, які можливі в полі функціонування концепту. Аналіз мовного матеріалу засвідчує такі регулярні предикації: запам'ятовування інформації, внесення інформації в пам'ять; володіння інформацією; відтворення інформації; втрата інформації.

Проаналізовано ознаки концепту Знання в контексті української паремійної картини світу, зокрема зв’язок з добром і злом.

Пам'ять може мати специфічний характер і стосуватись якогось 3 аспектів життя чи діяльності людини. Подібно до інших когнітивних функцій пам'ять людини може бути розвинута різною мірою, що знаходить відображення в мовному матеріалі.

Пам'ять постає у мові як уявний пристрій чи орган, котрий має локалізацію, асоціюється з фізичними відчуттями, може контролюватись зусиллями суб'єкта або функціонувати незалежно від його волі.

Суб'єктом пам'яті може виступати як індивідуальний носій, так i суспільство, колектив. Колективна пам'ять виражається в проявах суспільно-історичного досвіду, суспільної свідомості.

Концепт Пам'ять $є$ складним гетерогенним та багатозначним універсальним утворенням, що має автономічний характер, оскільки наявність бінарних опозицій $\epsilon$ конститутивною ознакою такого концепту, тому його структуру можна представити через ряд опозицій.

Розглянуто основні аспекти взаємодії концептів Знання та Пам'ять, що разом з мисленням, мовою, сприйняттям становлять сутність буття людини. Окреслено контексти та умови, в котрих вони $\epsilon$ взаємозамінними. Так, лексема пам'ятати є еквівалентом знати, коли ідеться про інформаційну пам'ять. Іншим прикладом є пропозитивна пам'ять - пам'ять суб'єкта про усвідомлені факти дійсності, що пов'язана з пропозитивним знанням. 


\section{ЛITЕРАТУРА}

1. Васильев Л.М. Семантика русского глагола. Москва : Высшая школа, 1981. $184 \mathrm{c.}$

2. Дмитровская М.А. Глаголы знания и мнения : дис. ... канд. фил. Наук : 10.02.01. Москва, 1985. 193 с.

3. Залевская А.А. Введение в психолингвистику. Москва, 1999. 382 с.

4. Зализняк А.А. Концептуализация забвения по данным русского языка. Когнитивное моделирование в лингвистике : материалы конференции. Москва : Ин-т языкознания РАН, 2004. С. 92-94.

5. Караванський С. Практичний словник синонімів української мови. Київ : Українська книга, 2000. 480 с.

6. Карасик В.И. Языковая личность: аспекты лингвистики и лингводидактики. Волгоград : Перемена, 1999. 208 с.

7. Мартинюк А.П. Концепт у дискурсивній парадигмі. Вісник Харківського національного університету ім. В.Н. Каразіна. Харків : Константа, 2006. С. 9-12.

8. Остапчук Я.В. Семантико-синтаксичні моделі речень 3 фактивними предикатами пам'яті. Наукові записки. Серія «Філологічна» : матеріали міжнар. наук.-практ. конф. Острог : Вид-во Національного університету «Острозька академія», 2010. Вип. 13. C. 498-505.

9. Рубинштейн С.Л. Основы общей психологии. Санкт-Петербург : Издательство «Питер», 2002. 720 с.

10. Словник синонімів української мови: В 2 т. / А.А. Бурячок, Г.М. Гнатюк, С.І. Головащук та ін. Київ : Наук. думка, 1999-2000. T. $1.1040 \mathrm{c}$.

11. Словник української мови: в 11 т. / І.К. Білодід (голова) та ін. Київ : Наукова думка, 1970-1980. Т. 61976.

12. Філософський енциклопедичний словник / За заг. ред. B.I. Шинкарука. Інститут філософії ім. Г.С. Сковороди НАН України, Київ : Абрис, 2002. 742 с.

13. Чейф У.Л. Память и вербализация пришлого опыта. Новое в зарубежной лингвистике. Москва : Радуга, 1983. Вып. 12: Прикладная лингвистика. С. 35-74.

14. Ayer A.J. The problem of Knowledge. London : Macmillan and Co LTD; New York : St. Martin's Press, 1956. 258 p.

15. Anderson J.R. Bower G.H. Human associative memory. Washington DC : Winston and Sons, 1973. 524 p.

16. Fortescue M. Thoughts about thoughts. Cognitive Linguistics. 2001. Vol. 12, No. 1. P. 15-45.

17. Fuster J.M. Cortex and Mind: Unifying Cognition. New York : Oxford University Press, 2005. 314 p. 
18. Schank R.C. Knowledge and Memory: The Real Story / ed. by R.S. Wyer. Hillsdale, NJ : Lawrence Erbaum Assosiates, 1995. P. 1-85.

19. Tulving E. Episodic and semantic memory. Organization of memory / ed. by E. Tulving, W. Donaldson. New York : Academic Press, 1972. P. 383-403.

\section{Information about the author: \\ Ostapchuk Ya. V.,}

Candidate of Philological Sciences, Associate Professor at the Foreign Languages Department Vasyl Stefanyk Precarpathian National University 57, Shevchenko str., Ivano-Frankivsk, 76018, Ukraine 